\title{
Binuclear $\mathrm{Cu}$ (II) and Co(II) Complexes of Tridentate Heterocyclic Shiff Base Derived from Salicylaldehyde with 4-Aminoantipyrine
}

\author{
Omar Hamad Shihab Al-Obaidi \\ Chemistry Department, College of Education for Women, Al-Anbar University, Ramadi, Iraq \\ Correspondence should be addressed to Omar Hamad Shihab Al-Obaidi, dromaralobaidi@yahoo.com \\ Received 24 September 2011; Revised 26 December 2011; Accepted 28 December 2011 \\ Academic Editor: Nick Katsaros
}

Copyright (C) 2012 Omar Hamad Shihab Al-Obaidi. This is an open access article distributed under the Creative Commons Attribution License, which permits unrestricted use, distribution, and reproduction in any medium, provided the original work is properly cited.

\begin{abstract}
New binuclear $\mathrm{Co}(\mathrm{II})$ and $\mathrm{Co}(\mathrm{II})$ complexes of ONO tridentate heterocyclic Schiff base derived from 4-aminoantipyrine with salicylaldehyde have been synthesized and characterized on the bases of elemental analysis, UV-Vis., FT-IR, and also by aid of molar conductivity measurements, magnetic measurements, and melting points. It has been found that the Schiff bases with $\mathrm{Cu}$ (II) or $\mathrm{Co}$ (II) ion forming binuclear complexes on $(1: 1)$ "metal : ligand" stoichiometry. The molar conductance measurements of the complexes in DMSO correspond to be nonelectrolytic nature for all prepared complexes. Distorted octahedral environment is suggested for metal complexes. A theoretical treatment of the formation of complexes in the gas phase was studied, and this was done by using the HyperChem-6 program for the molecular mechanics and semi-empirical calculations. The free ligand and its complexes have been tested for their antibacterial activities against two types of human pathogenic bacteria: the first type (Staphylococcus aureus) is Gram positive and the second type (Escherichia coli) is Gram negative (by using agar well diffusion method). Finally, it was found that compounds show different activity of inhibition on growth of the bacteria.
\end{abstract}

\section{Introduction}

Amino heterocyclic compounds containing two or more potential donor centers play an important role in the study of competitive reactivity of an bidentate ligand system [1]. Heterocyclic phenazone and their derivatives (4-aminoantipyrine) are known to act as bidentate or tridentate ligands when coordinated to metal ion [2].

Phenazone ligand can form mononuclear and binuclear complexes [3-5].

Transition metal complexes containing a salicylaldehyde are commonly found in biological media and play important roles in processes such as catalysis of drug interaction with biomolecules [6]. Phenazone Schiff base chemistry is less extensive, and our laboratory has been exploring this chemistry [7-10].

In this paper we are reporting the synthesis of the binuclear $\mathrm{Co}(\mathrm{II})$ and $\mathrm{Cu}$ (II) complexes of some heterocyclic Schiff base ligands (Figure 1) containing 4-aminoantipyrine. Spectral and magnetic studies have been used to characterize the structure of the complexes.

\section{Experimental}

2.1. Physical Measurements. A Fisher-100 infrared spectrophotometer was used to record the IR spectra as $\mathrm{KBr}$ and CsI disc, and UV/VIS spectra were measured by a HITACHI U-2000 spectrophotometer. Determination of all metals percentage by atomic absorption spectrophotometry on AA680G (Shimadzu). Electrical conductance was measured on conductivity CDC304 (Jenway4070) melting points determined by an electric heated block apparatus (GallenKamp) and were uncorrected. Room temperature magnetic susceptibility measurements were carried out on a B.M 6 BRUKER type magnets, balance. Diamagnetic correction was done using pascal constants.

2.2. Materials. All the chemicals and solvents used for the synthesis were reagent grade and procured from $(\mathrm{BDH}$ chemicals or Sigma-Aldrich or Fluka). Metal salts were purchased from E. Merck and used as received. All solvents were dried and purified before used.

2.2.1. Preparation of the Schiff Base Ligands (L1 and L2). The ligands were prepared by condensation of 4 -aminoantipyrine 


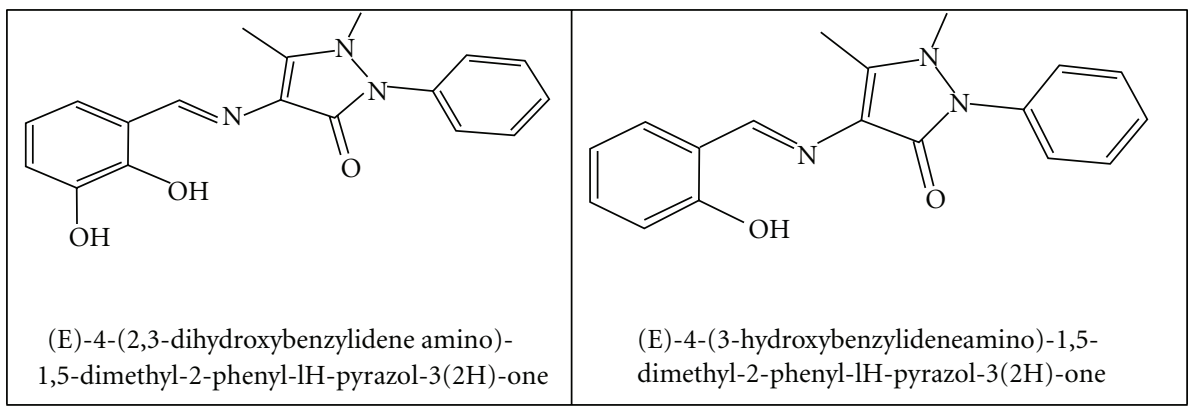

FIgURE 1: Structure of the ligands L1 and L2.

TABLe 1: Analytical and physical data of all the complexes.

\begin{tabular}{|c|c|c|c|c|c|c|c|c|c|c|}
\hline \multirow[t]{2}{*}{ No. } & \multirow[t]{2}{*}{ Complexes/FW } & \multirow[t]{2}{*}{ Colour } & \multirow{2}{*}{$\begin{array}{c}\Delta \mathrm{M} \\
\left(\Omega^{-1} \mathrm{~cm}^{2} \mathrm{~mol}^{-1}\right) \\
\text { In DMSO }\end{array}$} & \multirow[t]{2}{*}{$\begin{array}{l}\text { M.P } \\
\left({ }^{\circ} \mathrm{C}\right)\end{array}$} & \multirow[t]{2}{*}{$\begin{array}{l}\text { Yield } \\
(\%)\end{array}$} & \multicolumn{5}{|c|}{$\begin{array}{l}\text { Elemental analysis } \\
\text { (\% found) \% Cal. }\end{array}$} \\
\hline & & & & & & $\mathrm{C}$ & $\mathrm{H}$ & M & $\mathrm{N}$ & $\mathrm{O}$ \\
\hline 1 & $\begin{array}{c}{\left[\mathrm{Cu}_{2}(\mathrm{~L} 1)_{2}\left(\mathrm{H}_{2} \mathrm{O}\right)_{2}\right]} \\
\mathrm{C}_{36} \mathrm{H}_{34} \mathrm{Cu}_{2} \mathrm{~N}_{6} \mathrm{O}_{8} / 805\end{array}$ & Light orange & 9 & $>240$ & 75 & $\begin{array}{c}53.66 \\
(53.61)\end{array}$ & $\begin{array}{l}4.25 \\
(4.21)\end{array}$ & $\begin{array}{c}15.77 \\
(15.73)\end{array}$ & $\begin{array}{c}10.43 \\
(10.39)\end{array}$ & $\begin{array}{l}15.88 \\
(15.84)\end{array}$ \\
\hline 2 & $\begin{array}{c}{\left[\mathrm{Cu}_{2}(\mathrm{~L} 2)_{2}\left(\mathrm{H}_{2} \mathrm{O}\right)_{4}\right]} \\
\mathrm{C}_{36} \mathrm{H}_{40} \mathrm{Cu}_{2} \mathrm{~N}_{6} \mathrm{O}_{8} / 811\end{array}$ & Orange & 7 & 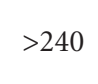 & 65 & $\begin{array}{c}53.26 \\
(53.21)\end{array}$ & $\begin{array}{l}4.97 \\
(4.93)\end{array}$ & $\begin{array}{c}15.65 \\
(15.60)\end{array}$ & $\begin{array}{c}10.35 \\
(10.30)\end{array}$ & $\begin{array}{r}15.77 \\
(15.73)\end{array}$ \\
\hline 3 & $\begin{array}{c}{\left[\mathrm{Co}_{2}(\mathrm{~L} 1)_{2}\left(\mathrm{H}_{2} \mathrm{O}\right)_{2}\right]} \\
\mathrm{C}_{36} \mathrm{H}_{34} \mathrm{Co}_{2} \mathrm{~N}_{6} \mathrm{O}_{8} / 796\end{array}$ & Light brown & 5 & $>240$ & 70 & $\begin{array}{c}54.28 \\
(54.23)\end{array}$ & $\begin{array}{c}4.30 \\
(4.26)\end{array}$ & $\begin{array}{c}16.07 \\
(16.02)\end{array}$ & $\begin{array}{l}14.80 \\
(14.76)\end{array}$ & $\begin{array}{c}10.55 \\
(10.50)\end{array}$ \\
\hline 4 & $\begin{array}{c}{\left[\mathrm{Co}_{2}(\mathrm{~L} 2)_{2}\left(\mathrm{H}_{2} \mathrm{O}\right)_{4}\right]} \\
\mathrm{C}_{36} \mathrm{H}_{40} \mathrm{Co}_{2} \mathrm{~N}_{6} \mathrm{O}_{8} / 802 \\
\end{array}$ & Brown & 8 & $>240$ & 75 & $\begin{array}{c}53.87 \\
(53.83) \\
\end{array}$ & $\begin{array}{c}5.02 \\
(4.98) \\
\end{array}$ & $\begin{array}{c}14.69 \\
(14.65) \\
\end{array}$ & $\begin{array}{c}10.47 \\
(10.41) \\
\end{array}$ & $\begin{array}{r}15.95 \\
(15.90) \\
\end{array}$ \\
\hline
\end{tabular}

with salicylaldehyde in ethanol. This preparation was performed as cited in the literature [11].

The general structures of ligands obtained from chemical analysis and spectral methods are given in Figure 1. The full name of the ligand will be replaced with (L1 and L2) for the rest of this paper.

2.2.2. Preparation of the Binuclear Metal Complexes. $1.00 \mathrm{~mm}$ of the ligands were dissolved in $30 \mathrm{~mL}$ of ethanol, and solution of $1.00 \mathrm{~mm}$ of the metal salts $\left[\mathrm{CuCl}_{2} \cdot 4 \mathrm{H}_{2} \mathrm{O}(0.20 \mathrm{~g})\right.$ ] in $15 \mathrm{~mL}$ ethanol was added dropwise with continuous stirring. The mixture was stirred further for $2-3 \mathrm{~h}$. at $80^{\circ} \mathrm{C}$. The precipitated solid was then filtered off, washed with diethylether, followed by cold ethanol, and dried under vacuum. The same method was applied for the preparation of $\left[\mathrm{CoCl}_{2} \cdot 6 \mathrm{H}_{2} \mathrm{O}\right]$ complexes by using the corresponding (L1 or L2) working in the same conditions with their respective molar ratio.

The physical properties of prepared complexes are listed in Table 1. The molar ratio of the complexes was determined according to the methods [12].

2.2.3. Study of Biological Activity for Ligands (L1 and L2) and Their Metal Complexes. The biological activity of the ligands and their metal complexes were studied against two selected types of bacteria which included Escherichia coli that are gram negative (-ve) and Staphylococcus aureus that are gram positive (+ve) to be cultivated and as control for the disc sensitivity test [13]. This method involves the exposure of the zone of inhibition toward the diffusion of microorganism on agar plat. The plates were incubated for $\left(24\right.$ hours), at $37^{\circ} \mathrm{C}$, and the zone of inhibition of bacteria growth around the disc was observed.

\section{Result and Discussion}

The Schiff bases ligands are soluble in common organic solvents. But its metal complexes are generally soluble in DMF and DMSO. The elemental analytical data of the complexes reveal that the compounds have "metal: ligand" an ion stoichiometry ratio of $1: 1$; the analytical data and other spectral analysis are in good agreement with the proposed stoichiometry of the complexes. The colors, yields, melting points, IR, and electronic absorption spectral data of all the compounds are presented in Table 2. The molar conductance of solutions of all the complexes in DMSO are in the range $[5-8,14] \Omega^{-1} \mathrm{~cm}^{2} \mathrm{~mole}^{-1}$ Table 1 . These observations suggest that all the complexes are nonelectrolytes [15] in DMSO $\left(1 * 10^{-3} \mathrm{M}\right)$ at room temperature. Polydentate complexes were obtained from $1: 1$ molar ratio reactions with metal ions and L1 and L2 ligands. The ligands L1 and L2 on reaction with $\mathrm{Cu}(\mathrm{II})$ and $\mathrm{Co}(\mathrm{II})$ salt yields complexes are corresponding to the formulas $\left[\mathrm{Cu}_{2}(\mathrm{~L} 1)_{2} \mathrm{H}_{2} \mathrm{O}\right.$ ], $\left[\mathrm{Co}_{2}(\mathrm{~L} 1)_{2} \mathrm{H}_{2} \mathrm{O}\right],\left[\mathrm{Cu}_{2}(\mathrm{~L} 2)_{2}\left(\mathrm{H}_{2} \mathrm{O}\right)_{4}\right]$, and $\left[\mathrm{Co}_{2}(\mathrm{~L} 2)_{2}\left(\mathrm{H}_{2} \mathrm{O}\right)_{4}\right]$.

3.1. Infrared Spectral Study. The most important infrared spectral bands of the investigated metal complexes in the present article are summarized in Table 2. The free Schiff base ligands are characterized by strong band at 1690, 1625, and $1270 \mathrm{~cm}^{-1}$ for L1, 1720,1625 , and $1290 \mathrm{~cm}^{-1}$ for L2 which 
TABLE 2: Characteristic IR and electronic spectral data of the metal complexes.

\begin{tabular}{|c|c|c|c|c|c|c|c|c|}
\hline \multirow{2}{*}{ No. } & \multirow{2}{*}{ Complexes } & \multirow{2}{*}{$\begin{array}{c}\mathrm{UV} / \mathrm{VIS} \\
\lambda \max \left(\mathrm{cm}^{-1}\right)\end{array}$} & \multirow{2}{*}{$\mu_{\text {eff. }} \mathrm{BM}$} & \multicolumn{5}{|c|}{ IR spectra $\mathrm{cm}^{-1}$} \\
\hline & & & & $v \mathrm{C}=\mathrm{O}$ & $v \mathrm{C}=\mathrm{N}$ & $v \mathrm{C}-\mathrm{O}$ & $v \mathrm{M}-\mathrm{N}$ & $v \mathrm{M}-\mathrm{O}$ \\
\hline 1 & {$\left[\mathrm{Cu}_{2}(\mathrm{~L} 1)_{2} \mathrm{H}_{2} \mathrm{O}\right]$} & $11085,16595,27990$ & 0.9 & $1650 \mathrm{~s}$ & $1600 \mathrm{~m}$ & $1265 \mathrm{~s}$ & $460 w$ & $530 \mathrm{w}$ \\
\hline 2 & {$\left[\mathrm{Cu}_{2}(\mathrm{~L} 2)_{2}\left(\mathrm{H}_{2} \mathrm{O}\right)_{4}\right]$} & $11080,16590,27995$ & 1.69 & $1670 \mathrm{~s}$ & $1610 \mathrm{~m}$ & $1260 \mathrm{~s}$ & $465 w$ & $535 \mathrm{w}$ \\
\hline 3 & {$\left[\mathrm{Co}_{2}(\mathrm{~L} 1)_{2} \mathrm{H}_{2} \mathrm{O}\right]$} & $10370,14380,18720,35690$ & 5.04 & $1665 \mathrm{~s}$ & $1610 \mathrm{~m}$ & $1270 s$ & $470 w$ & $520 \mathrm{w}$ \\
\hline 4 & {$\left[\mathrm{Co}_{2}(\mathrm{~L} 2)_{2}\left(\mathrm{H}_{2} \mathrm{O}\right)_{4}\right]$} & $10375,14385,18725,35695$ & 4.90 & $1660 \mathrm{~s}$ & $1590 \mathrm{~m}$ & $1270 \mathrm{~s}$ & $460 w$ & $515 \mathrm{w}$ \\
\hline
\end{tabular}

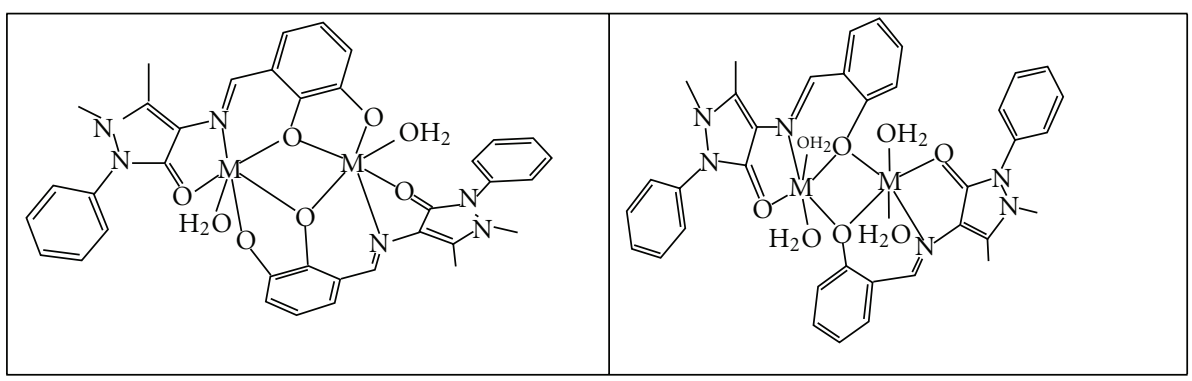

Figure 2: The proposed structure of the complexes where $\mathrm{M}=\mathrm{Cu}(\mathrm{II})$ or $\mathrm{Co}(\mathrm{II})$ of the ligands L1 and L2.

may be ascribed to the stretching vibrations of $\mathrm{C}=\mathrm{O}$ groups, $\mathrm{C}=\mathrm{N}$ (imine) and $\mathrm{C}-\mathrm{O}$ (phenolic) groups, respectively [710]. The band at $1630-1620 \mathrm{~cm}^{-1}$ due to the stretching mode of the $\mathrm{C}=\mathrm{N}$ group in the spectrum of the free ligands shows a remarkable negative shift with splitting in the 1590$1610 \mathrm{~cm}^{-1}$ region in all the complexes spectra suggesting that the coordinating azomethine nitrogen atoms of the Schiff bases are involved in the complexes formation [7-10].

In the spectra of all binuclear complexes, the phenolic band at $1260-1270 \mathrm{~cm}^{-1}$ is shifted to lower frequency (10$\left.30 \mathrm{~cm}^{-1}\right)$. It is suggested that the oxygen atom of this phenolic $(\mathrm{C}-\mathrm{O})$ group is bridged to the metal ions. An additional band at $1160 \mathrm{~cm}^{-1}$ suggests that water molecules are coordinated to metal ion $[16,17]$. This band may be assigned to water molecule $\mathrm{OH}$ heterocyclic ring vibration at 1580 $1200 \mathrm{~cm}^{-1}$. Other band of $\mathrm{M}-\mathrm{O}$ and $\mathrm{M}-\mathrm{N}$ bands appear respectively at $535-515,460-470 \mathrm{~cm}^{-1}$ Table 2 .

\subsection{Electronic Spectra and Magnetic Measurements. The elec-} tronic spectra were recorded in DMSO. In the spectrum of the ligand, the bands in the $380-340 \mathrm{~nm}$ range are assigned to the $n-\pi^{*}$ transitions of the azomethine group. During the formation of the complexes, these bands are shifted to lower wavelength, suggesting that the nitrogen atom of the azomethine group is coordinated to the metal ion. The values in the $325-245 \mathrm{~nm}$ range are attributed to the $\pi-\pi^{*}$ transition of the aromatic rings. In the spectra of the complexes, these bands are shifted slightly to lower wavelength.

3.3. $\mathrm{Cu}(\mathrm{II})$ Complexes. On the basis of the magnetic moment measurements, the $\mathrm{Cu}$ (II) complexes at room temperature probably have a binuclear structure with phenolic oxygen bridges. The magnetic moment lies in the range 0.9-1.69 B.M (for per $\mathrm{Cu}^{+2}$ ) Table 1 , and this is abnormally small consistent with a dimeric structure $[18,19]$.

The electronic spectra of the copper complexes Table 1 recorded in DMSO supported a near octahedral geometry for them and support the proposal that $\mathrm{H}_{2} \mathrm{O}$ groups are coordinated axially to $\mathrm{Cu}$ (II) ions [10]. The spectrum of the $\mathrm{Cu}$ (II) complexes exhibits absorption bands at 11085, 16595, and $27990 \mathrm{~cm}^{-1}$.

These bands may be considered to the following three spin allowed [20] transitions: ${ }^{2} \mathrm{~B}_{1} \mathrm{~g} \rightarrow{ }^{2} \mathrm{~A}_{1} \mathrm{~g}\left(d x^{2}-\right.$ $\left.y^{2} \rightarrow d z^{2}\right),{ }^{2} \mathrm{~B}_{1} \mathrm{~g} \rightarrow{ }^{2} \mathrm{~B}_{2} \mathrm{~g}\left(d x^{2}-y^{2} \rightarrow d z y\right)$, and ${ }^{2} \mathrm{~B} \rightarrow$ ${ }^{2} \mathrm{Eg}\left(d x^{2}-y^{2} \rightarrow d x y, d y z\right)$, and these transitions suggest $\mathrm{D}_{4 \mathrm{~h}}$ symmetry. The energy level sequence will depend on the amount of tetragonal distortion due to ligand field and Jahn Tellar distortion effect.

3.4. Co(II) Complexes. At room temperature the magnetic moment measurements of $\mathrm{Co}$ (II) complexes at 4.90-5.04 B.M correspond to three unpaired electrons, Table 1.

The electronic spectra of all the $\mathrm{Co}(\mathrm{II})$ complexes display absorption at 10370,14380, 18720, and $356960 \mathrm{~cm}^{-1}$; these bands may be assigned to the following transitions: ${ }^{4} \mathrm{~T}_{1} \mathrm{~g}(\mathrm{~F}) \rightarrow{ }^{4} \mathrm{~T}_{2} \mathrm{~g}\left(\nu_{1}\right),{ }^{4} \mathrm{~T}_{1} \mathrm{~g} \rightarrow{ }^{4} \mathrm{~A}_{2} \mathrm{~g}\left(\nu_{2}\right)$, and ${ }^{4} \mathrm{~T}_{1} \mathrm{~g}(\mathrm{~F}) \rightarrow{ }^{4} \mathrm{~T}_{2} \mathrm{~g}(\mathrm{P})\left(\nu_{3}\right)$, respectively [21]. It is difficult to give the assignments for the fourth band, and it may be due to chargetransfer. The position of electronic spectral bands indicates that these complexes have distorted octahedral geometry $[17,21,22]$.

3.5. The Proposed Structure. According to the results obtained from (ir, uv/vis, molar ratio, molar conductivity, and atomic absorption) measurements for the prepared complexes, the proposed molecular structure of the complexes has an octahedral structure as shown in Figure 2. 


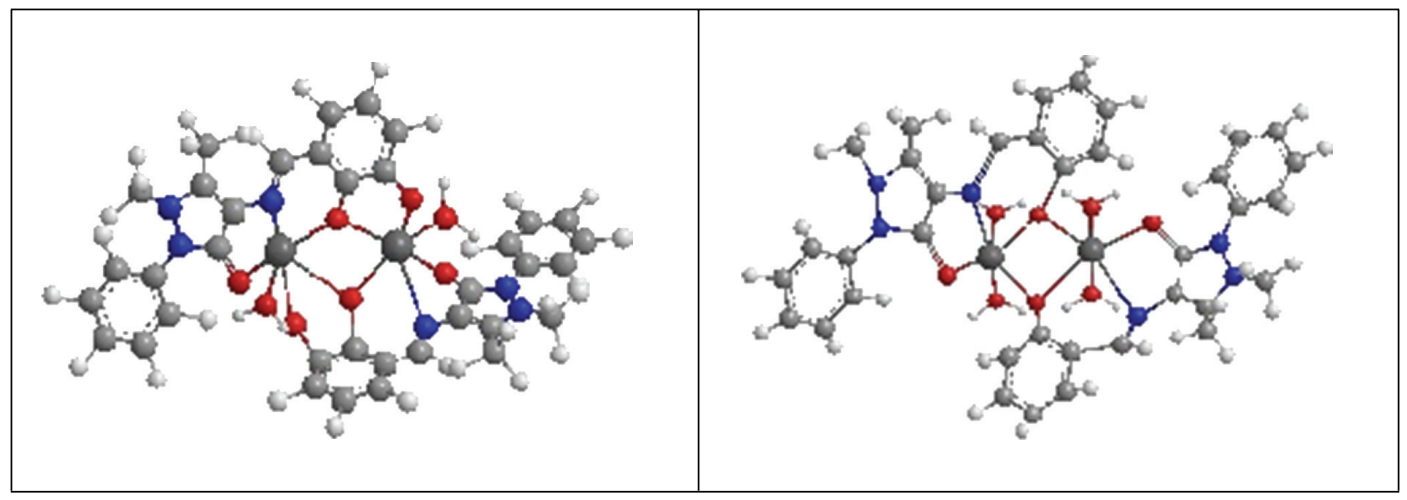

FIgURE 3: The optimized structural geometry of $\mathrm{Cu}(\mathrm{II})$ complexes.

TABLE 3: Structural parameters, bond length $\left({ }^{\circ} \mathrm{A}\right)$, and angles $\left({ }^{\circ}\right)$ of the $\left[\mathrm{Cu}_{2}(\mathrm{~L} 2)_{2}\left(\mathrm{H}_{2} \mathrm{O}\right)_{4}\right]$ complex.

\begin{tabular}{|c|c|c|c|}
\hline \multicolumn{4}{|c|}{ Parameters } \\
\hline \multicolumn{2}{|c|}{ Bond lengths $\left({ }^{\circ} \mathrm{A}\right)$} & \multicolumn{2}{|c|}{ Bond angles $\left({ }^{\circ}\right)$} \\
\hline & & $\mathrm{O}(19)-\mathrm{Cu}(50)-\mathrm{O}(52)-\mathrm{H}(85)$ & 179.9998 \\
\hline $\mathrm{Cu}(136)-\mathrm{O}(138)$ & 1.5230 & $\mathrm{O}(19)-\mathrm{Cu}(50)-\mathrm{O}(52)-\mathrm{H}(86)$ & -0.0001 \\
\hline $\mathrm{Cu}(135)-\mathrm{O}(137)$ & 1.5230 & $\mathrm{O}(24)-\mathrm{Cu}(50)-\mathrm{O}(52)-\mathrm{H}(85)$ & 174.1519 \\
\hline $\mathrm{O}(134)-\mathrm{Cu}(135)$ & 2.0400 & $\mathrm{O}(24)-\mathrm{Cu}(50)-\mathrm{O}(52)-\mathrm{H}(86)$ & -5.8480 \\
\hline $\mathrm{O}(129)-\mathrm{Cu}(135)$ & 2.3621 & $\mathrm{O}(30)-\mathrm{Cu}(50)-\mathrm{O}(52)-\mathrm{H}(85)$ & -40.8405 \\
\hline $\mathrm{O}(129)-\mathrm{Cu}(136)$ & 1.9129 & $\mathrm{O}(30)-\mathrm{Cu}(50)-\mathrm{O}(52)-\mathrm{H}(86)$ & 139.1596 \\
\hline $\mathrm{N}(125)-\mathrm{Cu}(136)$ & 2.3774 & $\mathrm{~N}(39)-\mathrm{Cu}(50)-\mathrm{O}(52)-\mathrm{H}(85)$ & 9.7808 \\
\hline $\mathrm{O}(116)-\mathrm{Cu}(136)$ & 1.8092 & $\mathrm{~N}(39)-\mathrm{Cu}(50)-\mathrm{O}(52)-\mathrm{H}(86)$ & -170.2191 \\
\hline $\mathrm{O}(110)-\mathrm{Cu}(136)$ & 1.3403 & $\mathrm{O}(43)-\mathrm{Cu}(50)-\mathrm{O}(52)-\mathrm{H}(85)$ & -3.4183 \\
\hline $\mathrm{O}(105)-\mathrm{Cu}(136)$ & 1.8419 & $\mathrm{O}(43)-\mathrm{Cu}(50)-\mathrm{O}(52)-\mathrm{H}(86)$ & 176.5818 \\
\hline $\mathrm{O}(105)-\mathrm{Cu}(135)$ & 1.7708 & $\mathrm{O}(6)-\mathrm{Cu}(49)-\mathrm{O}(51)-\mathrm{H}(83)$ & -179.9999 \\
\hline $\mathrm{N}(101)-\mathrm{Cu}(135)$ & 1.3875 & $\mathrm{O}(6)-\mathrm{Cu}(49)-\mathrm{O}(51)-\mathrm{H}(84)$ & 0.0011 \\
\hline $\mathrm{O}(92)-\mathrm{Cu}(135)$ & 1.5551 & $\mathrm{~N}(15)-\mathrm{Cu}(49)-\mathrm{O}(51)-\mathrm{H}(83)$ & -122.7109 \\
\hline $\mathrm{Cu}(50)-\mathrm{O}(52)$ & 1.5228 & $\mathrm{~N}(15)-\mathrm{Cu}(49)-\mathrm{O}(51)-\mathrm{H}(84)$ & 57.2900 \\
\hline $\mathrm{Cu}(49)-\mathrm{O}(51)$ & 1.5227 & $\mathrm{O}(19)-\mathrm{Cu}(49)-\mathrm{O}(51)-\mathrm{H}(83)$ & 41.5484 \\
\hline $\mathrm{O}(48)-\mathrm{Cu}(49)$ & 2.0398 & $\mathrm{O}(19)-\mathrm{Cu}(49)-\mathrm{O}(51)-\mathrm{H}(84)$ & -138.4507 \\
\hline $\mathrm{C}(47)-\mathrm{O}(48)$ & 1.4033 & $\mathrm{O}(43)-\mathrm{Cu}(49)-\mathrm{O}(51)-\mathrm{H}(83)$ & 37.5946 \\
\hline $\mathrm{C}(46)-\mathrm{H}(82)$ & 1.1000 & $\mathrm{O}(43)-\mathrm{Cu}(49)-\mathrm{O}(51)-\mathrm{H}(84)$ & -142.4044 \\
\hline $\mathrm{C}(46)-\mathrm{C}(47)$ & 1.0149 & $\mathrm{O}(48)-\mathrm{Cu}(49)-\mathrm{O}(51)-\mathrm{H}(83)$ & 37.5946 \\
\hline $\mathrm{C}(45)-\mathrm{H}(81)$ & 1.1000 & $\mathrm{O}(48)-\mathrm{Cu}(49)-\mathrm{O}(51)-\mathrm{H}(84)$ & 142.4044 \\
\hline $\mathrm{C}(45)-\mathrm{C}(46)$ & 1.1328 & $\mathrm{C}(47)-\mathrm{O}(48)-\mathrm{Cu}(49)-\mathrm{O}(6)$ & -155.1509 \\
\hline $\mathrm{C}(44)-\mathrm{H}(80)$ & 1.1000 & $\mathrm{C}(47)-\mathrm{O}(48)-\mathrm{Cu}(49)-\mathrm{N}(15)$ & -34.7220 \\
\hline $\mathrm{C}(44)-\mathrm{C}(45)$ & 1.0148 & $\mathrm{C}(47)-\mathrm{O}(48)-\mathrm{Cu}(49)-\mathrm{O}(19)$ & 55.8245 \\
\hline $\mathrm{O}(43)-\mathrm{Cu}(49)$ & 2.3617 & $\mathrm{C}(47)-\mathrm{O}(48)-\mathrm{Cu}(49)-\mathrm{O}(43)$ & 52.8179 \\
\hline $\mathrm{O}(43)-\mathrm{Cu}(50)$ & 1.9130 & $\mathrm{C}(47)-\mathrm{O}(48)-\mathrm{Cu}(49)-\mathrm{O}(51)$ & -127.1821 \\
\hline $\mathrm{O}(30)-\mathrm{Cu}(50)$ & 1.8090 & $\mathrm{Cu}(50)-\mathrm{O}(43)-\mathrm{Cu}(49)-\mathrm{O}(48)$ & 180.000 \\
\hline $\mathrm{C}(29)-\mathrm{C}(37)$ & 1.0468 & $\mathrm{Cu}(50)-\mathrm{O}(43)-\mathrm{Cu}(49)-\mathrm{O}(51)$ & 180.000 \\
\hline $\mathrm{C}(28)-\mathrm{N}(39)$ & 1.0144 & $\mathrm{C}(42)-\mathrm{O}(43)-\mathrm{Cu}(50)-\mathrm{O}(19)$ & -150.107 \\
\hline $\mathrm{C}(28)-\mathrm{C}(29)$ & 1.1317 & $\mathrm{C}(42)-\mathrm{O}(43)-\mathrm{Cu}(50)-\mathrm{O}(24)$ & -143.209 \\
\hline $\mathrm{C}(27)-\mathrm{O}(30)$ & 1.1265 & $\mathrm{C}(42)-\mathrm{O}(43)-\mathrm{Cu}(50)-\mathrm{O}(30)$ & 66.7882 \\
\hline $\mathrm{C}(27)-\mathrm{C}(28)$ & 0.9997 & $\mathrm{C}(42)-\mathrm{O}(43)-\mathrm{Cu}(50)-\mathrm{N}(39)$ & 18.0306 \\
\hline $\mathrm{N}(26)-\mathrm{C}(31)$ & 0.9735 & $\mathrm{C}(42)-\mathrm{O}(43)-\mathrm{Cu}(50)-\mathrm{O}(52)$ & 32.7885 \\
\hline $\mathrm{N}(26)-\mathrm{C}(27)$ & 1.0636 & $\mathrm{Cu}(49)-\mathrm{O}(43)-\mathrm{Cu}(50)-\mathrm{O}(19)$ & -2.8955 \\
\hline $\mathrm{N}(25)-\mathrm{C}(38)$ & 0.9597 & $\mathrm{Cu}(49)-\mathrm{O}(43)-\mathrm{Cu}(50)-\mathrm{O}(24)$ & 4.0021 \\
\hline & & $\mathrm{Cu}(49)-\mathrm{O}(43)-\mathrm{Cu}(50)-\mathrm{O}(30)$ & -146.00 \\
\hline
\end{tabular}

3.6. Theoretical Study. The ball and cylinders and some of selected structural parameters (bond length and angles) of the optimized geometries are shown in Figure 3 and Table 3.

As shown in this figure, there is no obvious trend for the variation of these parameters. The values of the bond length and angles of the optimized geometries are quite similar to the experimental results of the corresponding compounds.

3.7. Antibacterial Studied. The ligand and its transition metal complexes were evaluated against different species of bacteria 


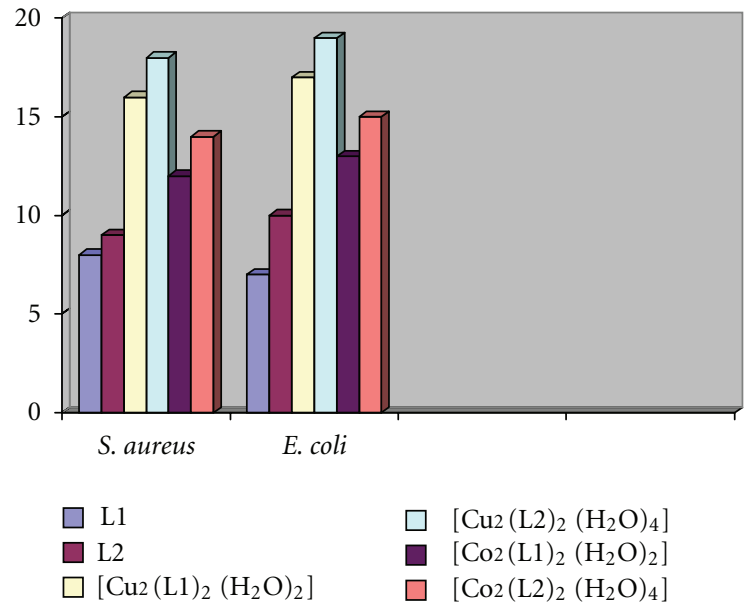

Figure 4: The effect of ligands and their metal complexes toward bacteria.

$[23,24]$. The antibacterial action of the ligands and the complexes of $\mathrm{Co}(\mathrm{II})$ and $\mathrm{Cu}(\mathrm{II})$ was checked by the disc diffusion technique. This was done on Staphylococcus aureus (gram positive) and Escherichia coli (gram negative) bacteria at $25^{\circ} \mathrm{C}$. The disc of whatman no. 4 filter paper having the diameter $6.00 \mathrm{~mm}$ was soaked in the solution of compounds in DMSO $\left(1.0 \mathrm{mg} \mathrm{cm}^{-1}\right)$. After drying it was placed on nutrient agar plates. The inhibition area wasobserved after $48 \mathrm{hr}$. DMSO used as control Figure 4 . The moderate effect was observed with $\mathrm{Cu}(\mathrm{II})$ complexes against Staphylococcus aureus, which is known as a resistant to most commercial antibiotic. The Schiff base ligands had more antibacterial activity than other ligands used, and this effect may be due to the presence of $-\mathrm{ph},-\mathrm{OH}$ and $-\mathrm{N}=\mathrm{C}-$ groups which are electron releasing. The antibacterial results evidently showed that the activity of the ligand compounds became more pronounced when coordination to the metal ions.

\section{References}

[1] A. D. Garnovskii, "Ambident chelating ligands," Zhurnal Neorganicheskoj Khimii, vol. 43, no. 9, pp. 1491-1500, 1998.

[2] M. Sönmez, I. Berber, and E. Akbaş, "Synthesis, antibacterial and antifungal activity of some new pyridazinone metal complexes," European Journal of Medicinal Chemistry, vol. 41, no. 1, pp. 101-105, 2006.

[3] S. M. E. Khalil, H. S. Seleem, B. A. El-Shetary, and M. Shebl, "Mono- and bi-nuclear metal complexes of schiff-base hydrazone (ONN) derived from o-hydroxyacetophenone and 2amino-4-hydrazino-6-methyl pyrimidine," Journal of Coordination Chemistry, vol. 55, no. 8, pp. 883-899, 2002.

[4] S. M. Saleem, S. Hussain, and Z. Nazir, "Gastric teratoma-a rare benign tumour of neonates," Annals of Tropical Paediatrics, vol. 23, no. 4, pp. 305-308, 2003.

[5] M. Weitzer and S. Brooker, "Bimetallic complexes of a structurally versatile pyridazine-containing Schiff-base macrocyclic ligand with pendant pyridine arms," Dalton Transactions, no. 14, pp. 2448-2454, 2005.
[6] P. O. Lumme and H. Knuuttila, "Studies on coordination compounds-VIII. Syntheses, structural, magnetic, spectral and thermal properties of some cobalt(II), nickel(II) and copper(II) complexes of 2-aminopyrimidine," Polyhedron, vol. 14, no. 12, pp. 1553-1563, 1995.

[7] M. Sönmez, A. Levent, and M. Şekerci, "Synthesis and characterization of $\mathrm{Cu}$ (II), $\mathrm{Co}(\mathrm{II}), \mathrm{Ni}(\mathrm{II})$, and $\mathrm{Zn}$ (II) complexes of a schiff base derived from 1-amino-5-benzoyl-4-phenyl-1Hpyrimidine-2-one and 3-Hydroxysalicylaldehyde," Synthesis and Reactivity in Inorganic and Metal-Organic Chemistry, vol. 33, no. 10, pp. 1747-1761, 2003.

[8] M. Sönmez, A. Levent, and M. Sekerci, "Synthesis, characterization, and thermal investigation of some metal complexes containing polydentate ONO-donor heterocyclic Schiff base ligand," Koordinatsionnaya Khimiya, vol. 30, no. 9, pp. 695699, 2004.

[9] M. Sönmez, "Synthesis and spectroscopic studies of $\mathrm{Cu}(\mathrm{II})$, $\mathrm{Co}(\mathrm{II}), \mathrm{Ni}(\mathrm{II})$ and $\mathrm{Zn}$ (II) schiff base complexes from 1-amino5-benzoyl-4-phenyl-1H pyrimidine-2-on with 2-hydroxynaphthaldehyde," Polish Journal of Chemistry, vol. 77, no. 4, pp. 397-402, 2003.

[10] M. Sönmez and M. Şekerci, "A new heterocyclic Schiff base and its metal complexes," Synthesis and Reactivity in Inorganic and Metal-Organic Chemistry, vol. 34, no. 3, pp. 489-502, 2004.

[11] E. Q. Gao, H. Y. Sun, D. Z. Liao, Z. H. Jiang, and S. P. Yan, "Synthesis of and magnetic interactions in binuclear $\mathrm{Cu}(\mathrm{II})$ $\mathrm{M}(\mathrm{II})(\mathrm{M}=\mathrm{Cu}, \mathrm{Ni}$ and $\mathrm{Mn})$ complexes of macrocyclic oxamido ligands," Polyhedron, vol. 21, no. 4, pp. 359-364, 2002.

[12] H. H. Jaffé, "A reëxamination of the hammett equation," Chemical Reviews, vol. 53, no. 2, pp. 191-261, 1953.

[13] Z. H. Chohan and M. Praveen, "Biological role of anions (sulfate, nitrate, oxalate and acetate) on the antibacterial properties of cobalt(II) and nickel(II) complexes with pyrazinedicarboxaimide derived, furanyl and thienyl compounds," MetalBased Drugs, vol. 6, no. 2, pp. 95-99, 1999.

[14] M. Sönmez and M. Sekerci, "complexes from 1-amino-5-benzoyl-4-phenyl-1H-pyrimidine-2-one with salicylaldehyde," Polish Journal of Chemistry, vol. 76, no. 7, pp. 907-914, 2002.

[15] W. J. Geary, "The use of conductivity measurements in organic solvents for the characterisation of coordination compounds," Coordination Chemistry Reviews, vol. 7, no. 1, pp. 81-122, 1971.

[16] K. Y. El-Baradie, "Mononuclear and binuclear Fe(III), Co(II), $\mathrm{Ni}(\mathrm{II})$, and $\mathrm{Cu}(\mathrm{II})$ complexes of 3,4' -dihydroxyazobenzene3',4-dicarboxylic acid and 3-carboxy-4-hydroxyphenylazo-3carboxy-4-hydroxynaphthalene," Monatshefte fur Chemie, vol. 136, no. 5, pp. 677-692, 2005.

[17] L. J. Bellamy, The Infrared Spectra of Complex Molecules, Chapman \& Hall, London, UK, 1978.

[18] A. B. P. Lever, Crystal Field Spectra. Inorganic Electronic Spectroscopy, Academic Press, Amsterdam, The Netherlands, 1st edition, 1968.

[19] S. Chandra and K. Gupta, "Chromium(III), manganese(II), iron(III), cobalt(II), nickel(II) and copper(II) complexes with a pentadentate, 15-membered new macrocyclic ligand," Transition Metal Chemistry, vol. 27, no. 2, pp. 196-199, 2002.

[20] A. B. P. Lever, Inorganic Electronic Spectroscopy, Elsevier, Amsterdam, The Netherlands, 2nd edition, 1984.

[21] S. Chandra and K. Gupta, "Twelve-, fourteen- and sixteenmembered macrocyclic ligands and a study of the effect of ring size on ligand field strength," Transition Metal Chemistry, vol. 27, no. 3, pp. 329-332, 2002.

[22] K. Nakamoto, Infrared Spectra of Inorganic and Coordination Compounds, Wiley-Interscience, New York, NY, USA, 1970. 
[23] M. A. Pujar, B. S. Hadimani, S. Meenakumari, S. M. Gadded, and Y. F. Neelgund, Current Science, vol. 55, p. 353, 1986.

[24] S. Chandra and S. D. Sharma, "Template synthesis of copper(II) complexes of two twelve-membered tetradentate nitrogen donor macrocyclic ligands," Journal of the Indian Chemical Society, vol. 79, no. 6, pp. 495-497, 2002. 


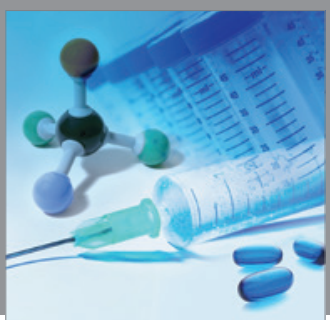

International Journal of

Medicinal Chemistry

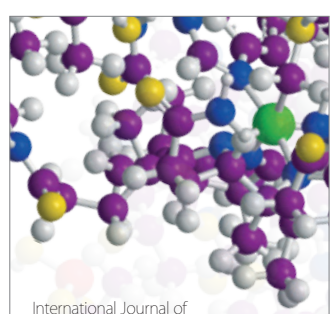

Carbohydrate Chemistry

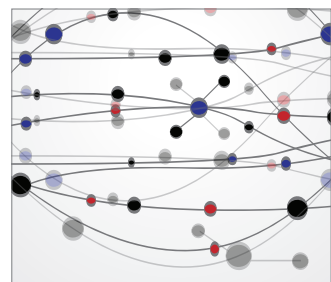

The Scientific World Journal
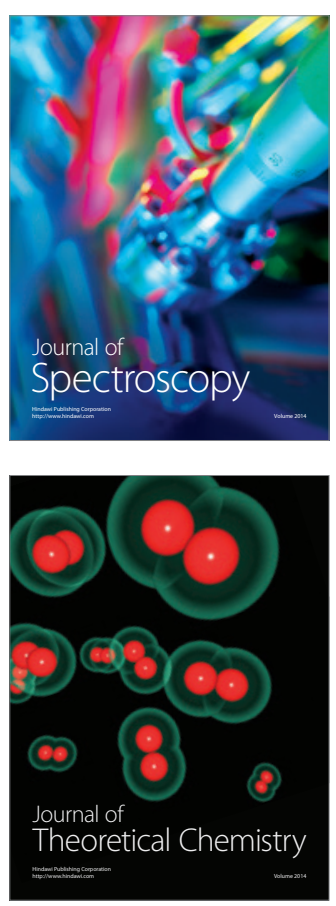
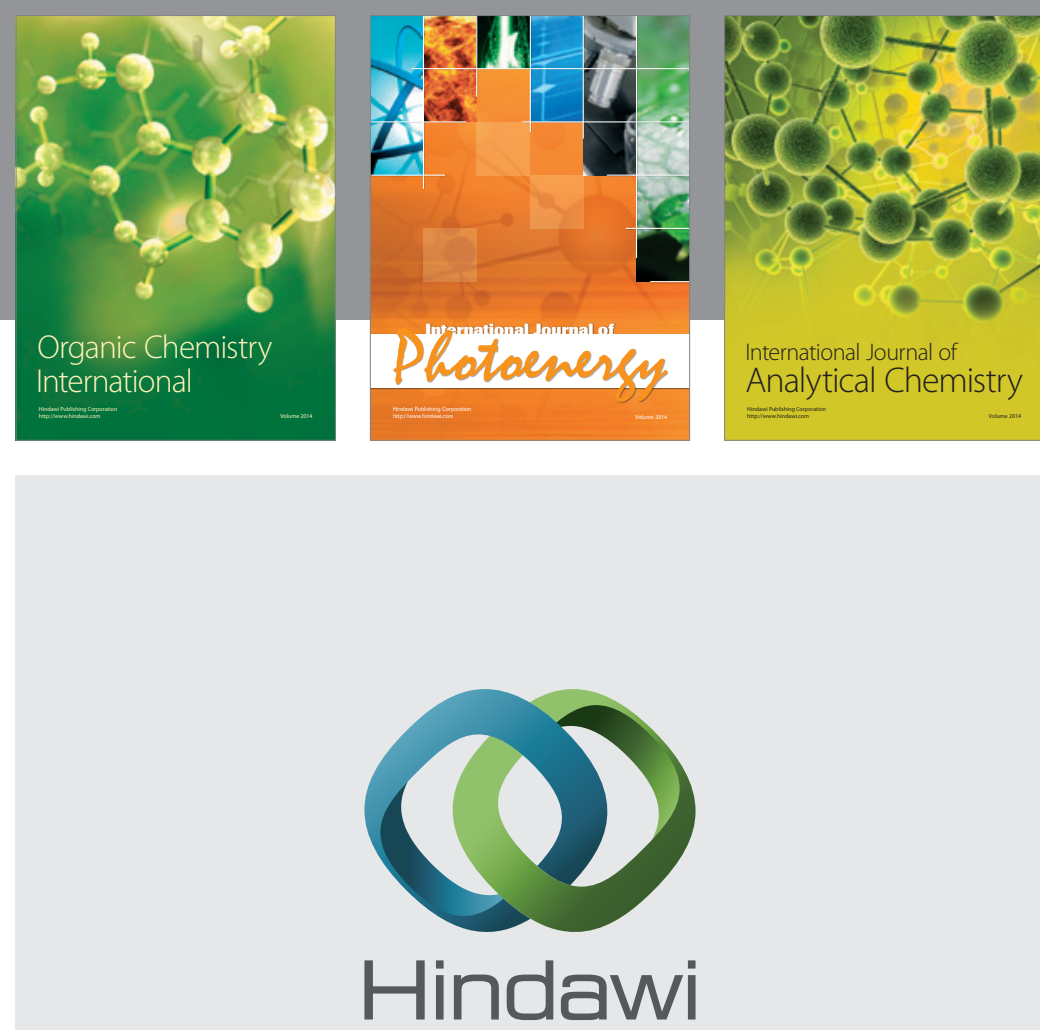

Submit your manuscripts at

http://www.hindawi.com
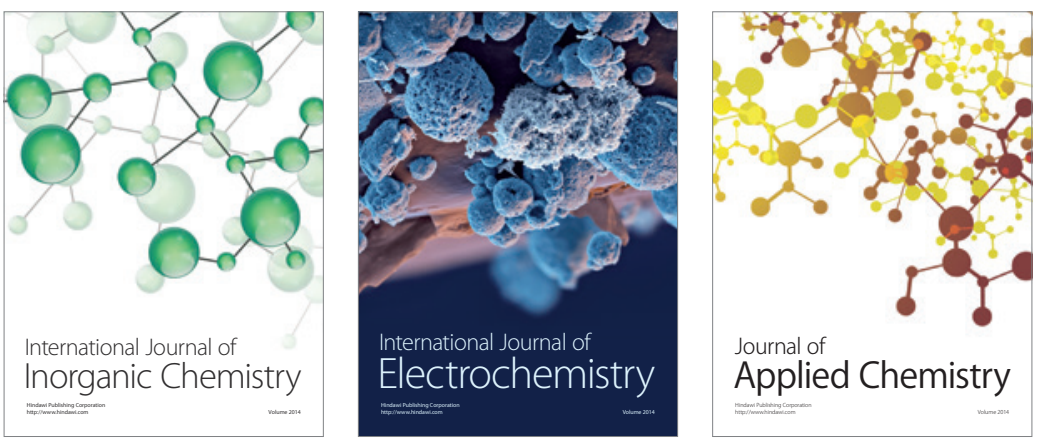

Journal of

Applied Chemistry
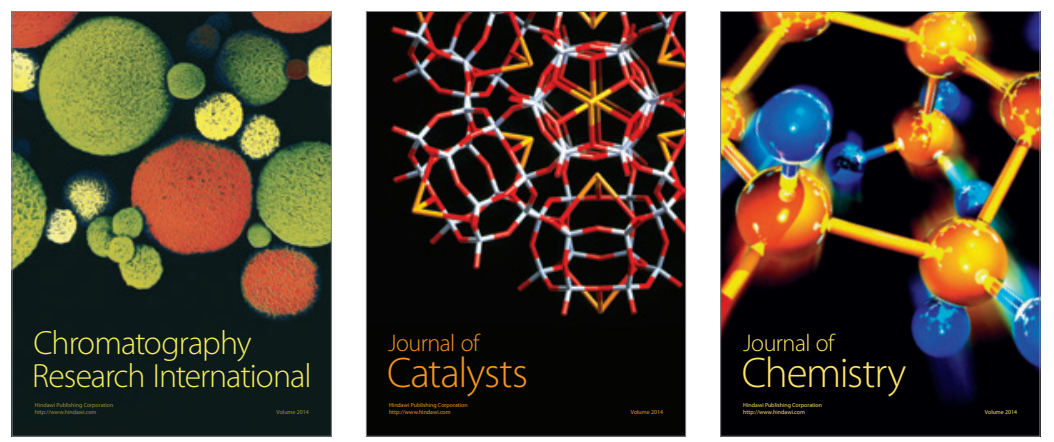
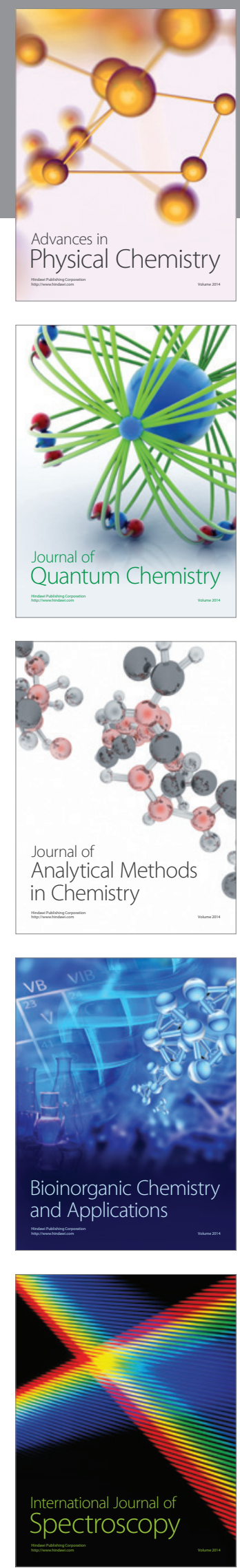